Forest by Stanley, Wolff, \&c., and also by myself in the north-east in part of the Ituri Province. ${ }^{2}$

When I first examined the pygmies from the central or northern part of the Ituri Province I thought I had lit upon an independent type of language in the dialect which I wrote down; but soon afterwards I found it to be almost identical with the language of the tall forest negroes of the Mbuba tribe. Comparing this Mbuba language, however, with vocabularies of Momvu, spoken further to the north, I found that Mbuba and Momvu were almost identical. This is the language which is spoken by the Congo pygmies now in London, brought over by Colonel Harrison, as anyone can easily ascertain by comparing their speech with my printed vocabularies in "The Uganda Protectorate." I visited these pygmies several times this summer in London. Not only did they recognise all the words in their language which $\mathbf{I}$ pro. nounced with care, but in all their answers to my questions it was clear that the dialect they spoke was identical, with the exception of a few words, with what I had transcribed close to their own homes in 1900 . Moreover, when they talk amongst themselves they make use of the same speech. It is, of course, quite possible they may have an esoteric language, really their own; but this at any rate has never been indicated as jet by any evidence.

There is one interesting feature, however, to be noted about the pygmies' use of the Mbuba language. Their pronunciation of it varies considerably between individuals Some pygmies almost entirely avoid the pronunciation of $K$, supplying its $p^{\prime}$ ace by a hiatus or gasp. This peculi arity does not seem to be characteristic of divisions of the tribe but of individuals and was observable amongst those in London as well as amongst the pygmies whom $\mathrm{I}$ en. countered myself in and around the porth-eastern corner of the Congo Forest. Of course the Mbuba language might be the original pygmy speech; but in that case they have impressed it on perhaps 100,000 forest-dwelling negroes of ordinary negro physical type, such as the Momvu, the Mbuba, \&c.

The Mbuba tongue is a polysyllabic language with a Bantu phonology and a grammar more akin to Madi and to the Nilotic family.

The Lendu people to the west of Lake Albert have a very peculiar language which, like the Momvu, has no known congeners, but I have never heard this used by pureblooded pygmies. On the other hand, the Lendu, though they offer a great diversity of physical types, present among themselves occasionally individuals markedly resembling the pygmies in appearance. I believe that this submerged pygmy type may be traced as far north as the Bongo country of the Sudan (where it is known as the "Red" Bongo), just as the pygmy physical type crops up in a slightly altere form in parts of the Uganda Protectorate to about as far east as the slopes of Mount Elgon, one of the distinguishing features of this type being the unmistakeably pygmy no:e, ${ }^{3}$ which is so very unlike the nose of the Bushman or Hottentot. The pygmy may be the oldest living African race and in the hurly-burly of 100,000 years or so may have lost the distinctive speech which it had, perhaps, developed by the time it reached Africa, though a good deal of this original African tongue may permeate the structure of other groups of more successful language families. In their present condition, in fact, the pygmies may forecast the state of negro Africa 200 or 300 years hence, in which it is quite possible that all negro languages except a Bantu jargon may have died out, their places being taken by English, French, Portuguese, Arabic, Italian, Spanish, German, and Dutch. But we know so little as yet about the whole question of the pygmies and their relations with other African types that no one has a right to be dogmatic on any subject connected with them.

I am, Sirs, yours faithfully,

Regent's Park, N.W., Sept. 11th, $1905 . \quad$ H. H. Johnston.

\section{THE CONDITION OF THE BLOOD VESSELS DURING SHOCK.}

To the Elditors of THE LANCET.

SiRs, - I have read Mr. John D. Malcolm's paper on this subject ${ }^{*}$ with much interest; it is one which essentially

2 Where the pygmies, like the surrounding forest negroes, speak Kibira, a broken-down Bantu speech allied to Manyema.

3 Very-bread and depressed, the extended ala beipg-nearty on level with the tips and bridge of the nose.

The LanceT, August 26th, 1905, p. 573 invites criticism. A complete criticism of his paper and of the hypothesis which he there puts forward to explain the phenomena of shock would oblige me to trespass unduly upon your valuable space and I shall therefore confine myself to a few points only.

Mr. Malcolm says: "If the vaso-motor centre is exhausted in shock some explanation is required of the fact that the whole surface of the body is not suffused with blood in that condition." I think the explanation is that flushing of the skin with blood only occurs as the result of dilatation of the superficial vessels when the general blood pressure is still high: if the general blood pressure is low and the dilatation of the superficial vessels is merely part of a generdl relaxation of the vascular system we should not expect to find flushing of the skin with blood. Moreover, in shock the exhaustion of the vaso-motor centres is not a sudden process but takes place slowly, the vessels in the splanchnic area first becoming dilated. And in the early stages of shock contraction of the peripheral arterioles occurs to compensate, if possible, for the fall in blood pressure brought about by the dilatation of the splanchnic blood vessels. Full dilatation of all the arterioles does not occur until the vaso-motor centres are completely exhausted and death is imminent.

I do not think that either Dr. G.W. Crile or myself ever maintained that there is a sudden change from extreme contraction of the blood ressels to complete relaxation when shock occurs. On the other hand, I believe the process to be extremely gradual. Complete relaxation of all the vessels controlled by the vaso-motor centres produces a fall in blood pressure which is at once fatal unless the blood pressure can be quickly raised again. The nearest approach to such a condition is seen in a patient suffering from shock who becomes sud denly collapsed as the result of being inadvertently raised in bed. Mr. Malcolm says: "I was led to believe that the phenomena of shock are due to a contraction of the arteries by noting that evidence of ansthing like a dilatation of the vessels generally, or in exposed parts of the splanchnic area alone, is usually wanting during life even in conditions of the most severe shock produced by abdominal operations." I cannot understand this statement as the engorgement of the splanchnic vessels with blood during severe shock is, I should have thought, beyond dispute. I have certainly repeatedly observed it both in patients during abdominal operations and in animals during experiments. And even suppcsing that contraction of the vessels and not dilatation is the cause of shock, where, then, does the blood go to? As the blood is incompressible it must go somewhere.

The chief argument, however, against Mr. Malcolm's theory is that adrenalin and other drugs which cause contraction of the peripheral arterioles are beneficial in cases of shock. If contraction of the vessels were the cause of shock then adrenalin instead of benefiting the condition should cause it. - I am, Sirs, yours faithfully,

Sept. 11th, 1905

P. LOCKHART MUMMERY.

\section{INSPECTION OF NURSING HOMES.}

\section{To the Editors of THE LANCET.}

SrRs, - It is to be hoped that the proposal to obtain registration and supervision of nursing institutions will not be relegated to a distant future through lack of the necessary advocacy in the medical press. Hospitals are protected by their appeals for public support, which entails a wholesome spirit of criticism, duly leavening the munificence of the charitable. State infirmaries, workhouses, and similar places for the sick are inspected as well as run out of the taxes and rates. Private establishments, however, escape any expert inspection, although they are attracting and carrying out an increasing amount of serious work.

It is inevitable that the struggling inseparable from keen competition, notwithstanding in many cases the best intentions, will occasion untold mischief in a certain proportion of so called nursing homes at the expense of patients who have accepted positions in which they are no longer able to decide for themselves what is the best course for them to follow unless Government steps in with a watchful care of the interests of the sick and an eye by no means unfriendly on the management.

All precedent establishes that institutions found to be ronest and successful in the work they carry out only gain in popularity and prestige by becoming responsible to the State for their efficiency. Experience of practice, private as well as hospital, should be an indispensable qualification of 
the gentlemen appointed inspectors, who should be required to give their whole time to the new duties. A few would suffice for Great Britain and Ireland.

$$
\text { I am, Sirs, yours faithfully, }
$$

Liverpool, Sept. 9th, 1905. GLYNN WhitTLE, M.D. Cantab.

\section{THE VALUE OH LEAD AS AN EXTERNAL APPLICATION IN INFLAMMATION. \\ To the Editors of THE LANCET.}

SiRs, - When reading the accounts given in modern surgical text-books of the various treatments of inflammation I have been struck by the fact that I find no mention of the use of lead as a local application. To those who are not in the habit of thus using lead lotion it will, I think, be a surprise to find how this application appears to modify many inflammatory processes. I am in the habit of applying lead lotion (I generally employ it tepid) on lint covered over with oiled skin to lacerated fingers and other lacerated and bruised wounds, to inflamed joints after injury, to inflamed bursæ patellæ, and to large bruised surfaces, particularly if suppuration is feared or threatened, and there is no doubt that the healing and absorption proceed as though the inflammatory action was in some way checked by the application. When there is evidence of inflammation spreading upwards from a wound hot fomentations to the wounded surface and lead applications to the reddened surfa:e of the skin I invariably find markedly assist in lessening the spreading inflammation. It may be not unlikely that this remedy is frequen'ly made use of, but our text-books of the present day are so full of the skilful discoveries of modern pathology and bacteriology that there is perhaps a danger of some of the older remedies being passed by unless their method of action can be explained and made to fit in with present-day explanations founded upon bacteriological research.

In view of these researches I do not pretend to suggest how lead acts when applied locally in these cases, but it appears safe to assume that in some way it assists the tissues in resisting the onslaught of whatever may have caused the inflammatory process. The recent knowledge which the study of bacteriology has afforded has so centred atiention upon the important action of bacteria and their + ffects upon the tissues, and the supreme importance of combating these, that the possible importance of efforts being made to assist the invaded tissues to exert to their full extent the undoubted power which they possess to resist and to overcome the in roads made upon their defences has, "perhaps, been thrown into the background. It is purely upon these defences and upon the power and opportunity which the tissues may possess for exerting to the full their defensive and protecting action that the success or otherwise of their defensive warfare against invasion must depend. The object of my communication is to draw attention to what appears to me to be the importance of paying attention to the aiding and strengthening of this defensive action, which is perhaps apt to be neglected in the modern rush to prevent or to destroy the hostile invaulers and it certainly seems to me that in lead applications we possess one method which is at any rate worthy of mention and of sufficient value to make us pause to consider whether it is not worth while to pay some little more attention to the possibilities of measures which may assist the defensive powers with which nature has provided the tissues and which, all important as they are, appear to me to have received in modern investigation less prominence than they deserve. I am, Sirs, yours faithfully,

H. Poole BERRY, M.B. Lond, M.R.C.S. Eng., Sept. 6th, $1905 . \quad$ Surgeon to the Grantham Hospital.

\section{NORMAN KERR LECTURESHIP. \\ Io the Editors of THE LANCET.}

SIRs,-Twenty-one years ago the late Dr. Norman Kerr founded the Society for the Study of Inebriety. It has been thought by many of his old friends that the coming of age of the society would afford a fitting opportunity to perpetuate his memory. The council have therefore decided to found in connexion with the society and in recognition of his enduring work in relation to the study of inebriety a "Norman Kerr" lectureship. It is believed that many well-known persons would be ready to deliver such a lecture before the society, both in honour of the founder thereof and for the furtherance of the investigations that he so ably inaugurated. It has also been suggested that a sum of $£ 300$ should be raised to form a fund, the interest of which should he available for the purposes of the lectureship. Towards this amount nearly $£ 100$ have already been promised. We feel sure that these proposals will meet with the approval of all the members and associates of the society and with others who knew Dr. Norman Kerr. All contributions towards the special "Norman Kerr Lectureship Fund" should be sent to the honorary treasurer of the same, Mr. McAdam Eocles, 124, Harley-street, W.-We are, Sirs, yours faith:ully,

\section{HaRRY CAM PBELL, President. \\ W. MCADAM ECCLES.}

Honorary Treasurer of Special Fund.

Sept. 11th, 1905

T. N. KEL.YNACK Honorary Secretary.

\section{RAINFALL IN AUGUST.}

\section{To the Editors of THE LANCET.}

Sirs, - In THE LANCET of Sept. 9th, p. 798, one of your Irish correspondents states that it rained continually on August 25th and 26 th for 39 hours in the north of Ireland, with a record of $2 \cdot 95$ inches, and that "the total rainfall in Ulster for the month was 7.82 inches." As it is not indicated what part of Ulster he writes from your readers might assume the abnormal rainfall to be general throughout that province. It was not so, for here on the north-west coast of Donegal, Ulster, the total rainfall for August was 5.17 inches ; for the last ten days of August (four rainless) the total rainfall was only 0.96 inch. In August, 1904, the record was 5.03 inches ; in 1903,6.27 inches.

I am, Sirs, Jours faithfully,

J. J. MACGRATH.

St. Helens, Dunfanaghy, Co. Donegal, Sept 9th, 1905.

\section{THE SALE OR PURCHASE OF A MEDICAL PRACTICE.}

To the Editors of THE LANCET.

SiRs, - May I be permitted to offer a few remarks on the above subject based on an experience of 30 years devoted solely to that particular branch of business and during which time a very large percentage of the transfers in England have passed through my hands? Without wishing to question your contributor's knowlt dge of the law I am sorry to find there are several suggestions as to clauses in agreement not at all in accord with vresent-day custom. Out and dried forms from text-books of mary years ago may be all very well in the transfer of a commer cial business but with the many peculiarities incident to the transfer of medical practices an agreement has to be prepared adapted to the requirement of each pirticular case and constant variations from stock forms are daily arising. I will deal with a few of the more important points in your contributor's articile.

First, as to the sale or lease of vendor's honse. In the sale of a medical practice the transfer of vendor's house is a most essential part of the goodwill and on no acconnt should a purchaser sign any document without this being secured to him in the agreement for transfer.

Clause 2.- Tour contributor assumes that appointments are not to be included in transfer. In probably 99 cases in a 100 all appointments are intended to be includted, seeing they usually form a very valuable portion of the practice and a special clause is inserted providing for the veridor doing his best to transfer them, with a proviso for a roduction in price in event of failure. The word custrmers is never employed in the transfer deed of a medical practice.

Clause 3.-Covenant to introduce purchaner. Your contributor says: "Any debts due to the practive collected after date of transfer shall belong to the purchaser." "This is an erroneous statement. All book debts due to vendor up to day of transfer belong to him and no matter when paid, whether to him or his successor, they are the sole roperty of vendor. In many cases a year's income or more is on the books at time of transfer and it would be manit.stly absurd that these should be given away to the purchaser who has had no part in earning them.

Clause 4.--Outgoings during introduction will not, as a rule, include rent of house. In a long introduction the 